\title{
INSTITUTIONAL SHAREHOLDERS, PRIVATE EQUITY, AND ANTITAKEOVER PROTECTION AT THE IPO STAGE
}

\section{MiCHAEL KLAUSNER $^{\dagger}$}

For well over a decade, institutional shareholders have been locked in battle with management of publicly held firms over matters of corporate governance generally, and takeover defenses specifically. The primary battles have been proxy contests over charter amendments. Institutional investors have opposed management proposals to amend charters in ways that would, in their view, impair governance and have supported shareholder proposals to amend charters in ways they believed would improve governance. The most common issues on which institutions have opposed management have involved takeover defenses. When management has proposed charter amendments to convert their boards from annually elected to classified boards, or to prevent shareholders from voting by written consent or calling special meetings, institutional investors have voted in opposition. In parallel fashion, when shareholders have submitted proposals to make charters more takeover-friendly-proposals to redeem poison pills, to submit poison pills to a shareholder vote, to declassify the boards of companies with classified boards, or to allow shareholders to vote by written consent or to call special meetings-institutions have voted in support of these proposals. In addition, institutions have supported shareholder governance proposals that are not directed specifically to takeover issues-including proposals requiring independent boards and board committees, separation of CEO and chairman positions, and confidential voting.

While the attention of institutional investors, academics, and the press has focused on proxy fights, thousands of companies have gone public with charters containing the same takeover defenses that institutions oppose and omitting the governance provisions that they advocate. Until recently, this phenomenon seems to have escaped the attention of institutional investors. Indeed, it occurred under the radar of corporate governance experts and advocates of all stripes.

+ Nancy and Charles Munger Professor of Business and Professor of Law, Stanford University. I would like to thank Bernie Black, Rob Daines, Laura Field, Ron Gilson, and Jeff Gordon for helpful comments on an earlier draft of this Article. 
Among academics, the supposed absence of takeover defenses in the charters of firms going public was taken as axiomatic. 'The fact that initial public offering (IPO) charters escaped the attention of institutional investors is particularly interesting because hundreds of the offending firms were funded by venture capital and leveraged buyout (LBO) funds, whose investors are the same institutions that wage corporate governance battles in the proxy context. ${ }^{2}$

Institutions have recently begun to make modest efforts to urge private equity funds ${ }^{3}$ to have their portfolio companies adopt takeover-friendly charters when they go public. Because such efforts coincided with the collapse of the IPO market, we cannot yet gauge their success. There may be a systematic reason, however, why companies with private equity backing will continue to go public with antitakeover protection in their charters despite the opposition of institutional shareholders. If so, the proxy battles of institutional shareholders may amount to a rear-guard action.

This Article chronicles the contrasting efforts of institutional investors in the proxy and IPO contexts and develops a hypothesis regarding why institutions may face substantial obstacles in trying to banish takeover defenses from the charters of companies going public. In Part IV, I examine the explanations that others have put forward for why companies include takeover defenses in their charters at the IPO stage, and I explain why those explanations fall short, at least in the context of companies with private equity fund investment.

' See, e.g., Frank H. Easterbrook \& Daniel R. Fischel, THE Economic STRUCTURE OF CORPORATE LAW 205 (1991) ("[F]irms go public in easy-to-acquire form: no poison pill securities, no supermajority rules or staggered boards. Defensive measures are added later, a sequence that reveals much."). The fact that this belief was inconsistent with the facts was uncovered by John C. Coates IV, Explaining Variation in Takeover Defenses: Blame the Lawyers, 89 CAL. L. REV. 1302, 1308, 1328 (2001), Robert Daines \& Michael Klausner, Do IPO Charters Maximize Firm Value? Antitakeover Protection in IPOs, 17 J.L. ECON. \& ORG. 83, 84 (2001), and Laura Casares Field \& Jonathan M. Karpoff, Takeover Defenses of IPO Firms, 57 J. FIN. 1857, 1858 (2002).

I addressed this issue in a preliminary fashion in Michael Klausner, Institutional Shareholders' Split Personality on Corporate Governance: Active in Proxies, Passive in IPOs, DIRECTORSHIP (The Directorship Search Group, New York, N.Y.), Jan. 2002, at 7.

"I will use the term "private equity fund" to refer to venture capital funds and leveraged buyout funds collectively. 


\section{INSTITUTIONAL SHAREHOLDERS AND TAKEOVER DEFENSES IN THE PROXY VOTING CONTEXT}

Although the phenomenon of institutional shareholder activism in the proxy context is well known, some documentation of the phenomenon may be helpful. The Investor Responsibility Research Center (IRRC) has collected data each year since 1986 on the results of proxy contests. ${ }^{4}$ Table 1 reports these data on two types of shareholder proposals: (a) proposals to repeal classified boards and (b) proposals either to redeem poison pills or to require the adoption of a pill to be ratified by shareholders. ${ }^{5}$

As Table 1 shows, there has been substantial and growing shareholder opposition to takeover defenses since the IRRC began collecting these data. Although the incidence of proxy fights over poison pills and staggered boards has fluctuated around a mean of $1.5 \%$ and $2.7 \%$, respectively, among firms in the IRRC sample, the average vote in favor of these proposals has increased two- to threefold bętween 1987 and 2002. For proposals opposing poison pills, the average vote

${ }^{4}$ In 1986, IRRC surveyed 1000 corporations. In 1987 and 1988, they increased their sample to 1200 and 1500 companies, respectively. In 1996, they increased the sample to 2000 . Then, in 1998 , they increased the sample to $\mathbf{4 0 0 0}$ for voting on management proposals but left the sample at 2000 for shareholder proposals. E-mail from Alesandra Monaco, IRRC, to Michael Klausner, Professor of Law, Stanford University Law School (Apr. 8, 2003, 3:39 PM PDT) (on file with author).

${ }^{5}$ The shareholder proposals reported in Table 1 include both proposals to redeem a poison pill and proposals to require shareholder ratification of the board's adoption of a pill. When a firm has both a poison pill and a classified board, it can ward off a hostile acquirer for up to two years. A classified board without a poison pill has essentially no impact on a hostile bid. A poison pill without a classified board can prevent a hostile bid for only as long as it takes for the bidder to launch a proxy battle to replace the target board with board members who will redeem the pill. If the target's charter allows shareholders to remove directors without cause and to vote by written consent, the proxy contest can be completed in roughly forty-five days. If a target's charter does not allow voting by written consent, but does allow fewer than ten percent of shareholders to call a special meeting, the proxy contest can be completed in approximately sixty-five days. If more than ten percent of shareholders are required to call a special meeting, then the proxy contest can be completed in approximately ninety days. If none of these methods of shareholder voting is available under a firm's charter, an acquirer must wait until the next annual meeting to mount a proxy contest in order to oust the target board. See Coates, supra note 1, at 1406 (discussing the effect of a company's annual meeting cycle on a bidder's attempt to begin a proxy fight). Shareholders at firms that do not allow shareholders to vote by written consent or to call a special meeting have made proposals asking management to support charter amendments that would allow such shareholder action. Institutions have supported those contests as well. Because they are not as numerous as proposals concerning classified boards and poison pills, however, I do not include that data here. 
rose from $29.4 \%$ to $60.2 \%$; and for proposals to declassify boards, the average vote rose from $17.5 \%$ to $61.6 \%$.

Table 1: Shareholder Proposals ${ }^{6}$

\begin{tabular}{|c|c|c|c|c||c|c|c|}
\hline \multicolumn{7}{|c||}{ Poison Pill Proposals } & \multicolumn{2}{c|}{ Classified Board Proposals } \\
\hline Year & $\begin{array}{c}\text { Size of } \\
\text { IRRC } \\
\text { Sample }\end{array}$ & $\begin{array}{c}\text { No. of } \\
\text { Proposals }\end{array}$ & $\begin{array}{c}\text { Percent } \\
\text { of IRRC } \\
\text { Sample }\end{array}$ & $\begin{array}{c}\text { Average } \\
\text { Vote }\end{array}$ & $\begin{array}{c}\text { No. of } \\
\text { Proposals }\end{array}$ & $\begin{array}{c}\text { Percent } \\
\text { of IRRC } \\
\text { Sample }\end{array}$ & $\begin{array}{c}\text { Average } \\
\text { Vote }\end{array}$ \\
\hline 1987 & 1200 & 32 & $2.7 \%$ & $29.4 \%$ & 22 & $1.8 \%$ & $16.4 \%$ \\
\hline 1988 & 1500 & 19 & $1.3 \%$ & $38.7 \%$ & 38 & $2.5 \%$ & $20.3 \%$ \\
\hline 1989 & 1500 & 20 & $1.3 \%$ & $41.5 \%$ & 50 & $3.3 \%$ & $21.8 \%$ \\
\hline 1990 & 1500 & 41 & $2.7 \%$ & $42.1 \%$ & 47 & $3.1 \%$ & $25.8 \%$ \\
\hline 1991 & 1500 & 40 & $2.7 \%$ & $44.8 \%$ & 42 & $2.8 \%$ & $28.3 \%$ \\
\hline 1992 & 1500 & 23 & $1.5 \%$ & $43.1 \%$ & 35 & $2.3 \%$ & $23.1 \%$ \\
\hline 1993 & 1500 & 18 & $1.2 \%$ & $44.3 \%$ & 34 & $2.3 \%$ & $31.9 \%$ \\
\hline 1994 & 1500 & 12 & $0.8 \%$ & $53.7 \%$ & 42 & $2.8 \%$ & $35.7 \%$ \\
\hline 1995 & 1500 & 10 & $0.7 \%$ & $45.2 \%$ & 65 & $4.3 \%$ & $39.1 \%$ \\
\hline 1996 & 2000 & 14 & $0.7 \%$ & $53.4 \%$ & 63 & $3.2 \%$ & $42.2 \%$ \\
\hline 1997 & 2000 & 18 & $0.9 \%$ & $54.9 \%$ & 42 & $2.1 \%$ & $43.8 \%$ \\
\hline 1998 & 2000 & 13 & $0.7 \%$ & $57.4 \%$ & 49 & $2.5 \%$ & $47.3 \%$ \\
\hline 1999 & 2000 & 27 & $1.4 \%$ & $61.9 \%$ & 63 & $3.2 \%$ & $47.3 \%$ \\
\hline 2000 & 2000 & 24 & $1.2 \%$ & $57.8 \%$ & 54 & $2.7 \%$ & $52.7 \%$ \\
\hline 2001 & 2000 & 22 & $1.1 \%$ & $57.0 \%$ & 46 & $2.3 \%$ & $52.4 \%$ \\
\hline 2002 & 2000 & 50 & $2.5 \%$ & $60.2 \%$ & 42 & $2.1 \%$ & $61.6 \%$ \\
\hline
\end{tabular}

Shareholder opposition to takeover defenses also appears in votes on management attempts to adopt classified boards. ${ }^{7}$ Table 2 presents IRRC data on these management proposals. In 1986, the management of eighty-eight companies, which amounted to $8.8 \%$ of the IRRC sample at the time, sought amendments. From 1986 to 2002, the percentage of sample companies attempting to adopt classified boards declined to $0.3 \%$ of the IRRC sample. This decline apparently reflects management realization that there is no point in even asking shareholders to support a classified board. The IRRC has data, beginning in 1996, on the results of these efforts to classify boards. Of eight-nine attempts for which the IRRC has outcome data, sixty-four proposals for classified boards passed. Among the sixty-four that passed,

'Investor Responsibility Research Center., at http://oa.irrc.com (n.d.) [hereinafter IRRC database].

7 Adoption of a classified board that will serve as an effective takeover defense requires a charter amendment, which requires a shareholder vote. DEL. CODE ANN. tit. $8, \S 242$ (2002). The adoption of a poison pill does not require a shareholder vote. Hence, in the context of shareholder voting on management proposals, there is no counterpart to shareholder proposals seeking to have management redeem a pill or to have pills subjected to shareholder ratification. 
however, there were many companies in which management held large blocks of shares. ${ }^{8}$

Table 2: Management Proposals to Adopt Classified Boards ${ }^{9}$

\begin{tabular}{|c|c|c|c|}
\hline Year & $\begin{array}{c}\text { Size of IRRC } \\
\text { Sample }\end{array}$ & $\begin{array}{c}\text { No. of } \\
\text { Proposals }\end{array}$ & $\begin{array}{c}\text { Percent of IRRC } \\
\text { Sample }\end{array}$ \\
\hline 1986 & 1000 & 88 & $8.8 \%$ \\
\hline 1987 & 1200 & 40 & $3.3 \%$ \\
\hline 1988 & 1500 & 26 & $1.7 \%$ \\
\hline 1989 & 1500 & 27 & $1.8 \%$ \\
\hline 1990 & 1500 & 26 & $1.7 \%$ \\
\hline 1991 & 1500 & 12 & $0.8 \%$ \\
\hline 1992 & 1500 & 5 & $0.3 \%$ \\
\hline 1993 & 1500 & 4 & $0.3 \%$ \\
\hline 1994 & 1500 & 5 & $0.3 \%$ \\
\hline 1995 & 1500 & 7 & $0.5 \%$ \\
\hline 1996 & 2000 & 8 & $0.4 \%$ \\
\hline 1997 & 2000 & 13 & $0.7 \%$ \\
\hline 1998 & 4000 & 13 & $0.3 \%$ \\
\hline 1999 & 4000 & 21 & $0.5 \%$ \\
\hline 2000 & 4000 & 10 & $0.3 \%$ \\
\hline 2001 & 4000 & 20 & $0.5 \%$ \\
\hline 2002 & 4000 & 11 & $0.3 \%$ \\
\hline
\end{tabular}

Although these shareholder voting data combine both institutional and individual votes, other IRRC data confirm institutions' opposition to takeover defenses. In 2000, the IRRC surveyed institutions regarding their voting policies. ${ }^{10}$ The respondents to the survey may not necessarily constitute a representative sample of institutions, and indeed the low response rate suggests that they do not." Nonetheless, the basic results of the survey, which are consistent with other evidence, can be viewed as broadly indicative of institutional investors' views of takeover defenses. Table 3 summarizes some of the IRRC survey's key findings. ${ }^{12}$ Among all survey respondents, 59\% consistently vote against management proposals to adopt classified boards,

8 IRRC database, supra note 6.

9 IRRC database, supra note 6.

${ }^{10}$ TIMOTHY M. HunT \& JASON D. MONTGOMERY, INVESTOR RESPONSIBILITY RESEARCH CTR., VOTING BY INSTITUTIONAL INVESTORS ON CORPORATE GOVERNANCE IsSUES 5 (2001) [hereinafter IRRC Survey].

"The IRRC sent surveys to "several hundred institutions" but recorded responses for only seventy-five. The responses included institutions that responded directly to the survey as well as institutions that have publicly available proxy voting guidelines, which IRRC used to fill out the survey. Id.

${ }^{12}$ Table 3 combines data reported from the IRRC Survey. Id. passim. 
and $65 \%$ vote in favor of shareholder proposals to repeal classified boards. Institutions oppose management control over poison pills as well, with $72 \%$ of survey respondents voting in favor of shareholder proposals that ask management to submit pills to shareholder vote before adoption. Some respondents express their opposition to takeover defenses symbolically as well, by withholding votes in elections of directors; 27\% responded positively to a survey question asking whether they "would consider" doing so where a company has a classified board. Among institutions, public pension plans are the most uniformly opposed to takeover defenses, and, not surprisingly, corporate pension plans are the least opposed.

Table 3: Responses to IRRC Survey (2000)

\begin{tabular}{|l|c|c|c|c|c|}
\hline & $\begin{array}{c}\text { Public } \\
\text { Pensions }\end{array}$ & $\begin{array}{c}\text { Corporate } \\
\text { Pensions }\end{array}$ & $\begin{array}{c}\text { Investment } \\
\text { Managers }\end{array}$ & $\begin{array}{c}\text { Universities \& } \\
\text { Foundations }\end{array}$ & Total \\
\hline $\begin{array}{l}\text { Management } \\
\text { Proposals to } \\
\text { Adopt Classified } \\
\text { Board }\end{array}$ & $\begin{array}{c}73 \% \\
\text { Oppose }\end{array}$ & $\begin{array}{c}25 \% \\
\text { Oppose }\end{array}$ & $\begin{array}{c}63 \% \\
\text { Oppose }\end{array}$ & $\begin{array}{c}40 \% \\
\text { Oppose }\end{array}$ & $\begin{array}{c}59 \% \\
\text { Oppose }\end{array}$ \\
\hline $\begin{array}{l}\text { Shareholder } \\
\text { Proposals to } \\
\text { Repeal } \\
\text { Classified Board }\end{array}$ & $\begin{array}{c}73 \% \\
\text { Favor }\end{array}$ & $\begin{array}{c}25 \% \\
\text { Favor }\end{array}$ & $\begin{array}{c}71 \% \\
\text { Favor }\end{array}$ & $\begin{array}{c}56 \% \\
\text { Favor }\end{array}$ & $\begin{array}{c}65 \% \\
\text { Favor }\end{array}$ \\
\hline $\begin{array}{l}\text { Shareholder } \\
\text { Proposals to Put } \\
\text { Pill to a Vote }\end{array}$ & $\begin{array}{c}86 \% \\
\text { Favor }\end{array}$ & $\begin{array}{c}25 \% \\
\text { Favor }\end{array}$ & $\begin{array}{c}71 \% \\
\text { Favor }\end{array}$ & $\begin{array}{c}56 \% \\
\text { Favor }\end{array}$ & $\begin{array}{c}72 \% \\
\text { Favor }\end{array}$ \\
\hline $\begin{array}{l}\text { Withhold Vote } \\
\text { for Director if } \\
\text { Board is } \\
\text { Classified }\end{array}$ & $\begin{array}{c}37 \% \\
\text { Would }\end{array}$ & $\begin{array}{c}0 \% \\
\text { Would } \\
\text { Consider }\end{array}$ & $\begin{array}{c}13 \% \\
\text { Would } \\
\text { Consider }\end{array}$ & $\begin{array}{c}45 \% \\
\text { Would } \\
\text { Consider }\end{array}$ & $\begin{array}{c}27 \% \\
\text { Would } \\
\text { Consider }\end{array}$ \\
\hline
\end{tabular}

The IRRC also reports that $57 \%$ of respondents consistently vote in favor of shareholder proposals to redeem poison pills, $82 \%$ of respondents vote against management proposals to prohibit voting by written consent, $78 \%$ of respondents vote against management proposals to prohibit shareholders from calling a special meeting, and $71 \%$ of respondents vote against the authorization of blank check preferred stock. ${ }^{13}$ Because the IRRC Survey does not break down these votes by type of institution, these responses do not appear in Table 3.

The responses to the IRRC survey are consistent with the Corporate Governance Policies of the Council of Institutional Investors (Council), a broad-based association of institutional investors that

${ }^{13}$ Id. at $29,51,62$. 
works to promote good corporate governance. Those policies include the following:

- "[D]irectors should be elected annually. (no classified boards)." ${ }^{14}$

- "A majority vote of common shares outstanding should be required to approve ... poison pills."

- "A majority vote of common shares outstanding should be required to approve... abridging or limiting the rights of common shares to ... call special meetings of shareholders or take action by written consent ..."16

Additional documentation of institutional investors' position regarding takeover defenses is found in the Institutional Shareholder Services' (ISS) Proxy Voting Manual (ISS Manual) which both advises subscribing institutions on how to vote their proxies and reflects commonly held positions among institutional shareholders. ${ }^{17}$ The ISS Manual advises as follows:

- Vote against staggered board proposals by management. ${ }^{18}$

- Vote for shareholder proposals asking that a company submit its poison pill to shareholder ratification. ${ }^{19}$

- Vote against management proposals to restrict shareholder action by written consent or special meeting. ${ }^{20}$

- Vote in favor of shareholder proposals to ease shareholder action by written consent or special meeting. ${ }^{21}$

This advice is absolute, in contrast to ISS advice on other issues where the recommendation is that institutions consider matters on a case-bycase basis. $^{22}$

${ }^{14}$ Council of Institutional Investors, Corporate Governance Policies I, at http://www. cii.org/dcwascii/web.nsf/doc/policies_index.cm (last visited Jan. 8, 2004) [hereinafter Policies].

${ }^{15}$ Id. at II.

${ }^{16} I d$.

17 Institutional Shareholder Services, The ISS Proxy Voting Manual (3d ed. 2003) [hereinafter ISS Manual].

${ }^{18} I d$. at 6.4 .

${ }^{19} I d$.

${ }^{20} I d$. at $6.12,6.14$.

${ }^{21} \mathrm{Id}$.

${ }^{22}$ One finds the same positions in the proxy voting guidelines of individual institutions. See, e.g., CalPERS, Governance Principles (last visited November 29, 2003) (recommending a collaborative approach to governance principle adoption), http://www. calpers-governance.org/principles/; Fidelity Investments, Fidelity Group of Mutual Funds and Corporate Governance (adopted July 2003) (recommending, generally, that shareholders vote against takeover defensive measures), http://personal.fidelity. 
Research on the impact of takeover defenses on shareholder wealth supports institutional investors' opposition to defenses, especially their opposition to classified boards. This research is by now well known, so there is no need to review it in detail, but the basic findings include: (a) staggered boards have a negative impact on share values; ${ }^{23}$ (b) firms that have adopted staggered boards amendments receive fewer takeover bids than other firms, and the bids that they do receive do not provide higher premiums than do the bids made for other firms; ${ }^{24}$ (c) following the adoption in the corporate charter of one of these provisions, management compensation tends to rise more than compensation at comparable firms without takeover protection in their charters, ${ }^{25}$ and (d) following the adoption of a takeover defense, free cash flow tends to increase. ${ }^{26}$

com/myfidelity/InsideFidelity/InvestExpertise/governance.html; TIIA-CrEF, POLICY STATEMENT ON CORPORATE GOVERNANCE 14 (n.d.) (stating that a company should make a "compelling case" before adopting a takeover defense), available at http://www.tiaa-cref.org/pubs/pdf/governance-policy.pdf.

${ }^{23}$ See generally Sanjai Bhagat \& Richard H. Jefferis, Voting Power in the Proxy Process: The Case of Antitakeover Charter Amendments, 30 J. FIN. ECON. 193, 203 (1991) (stating that returns are "consistent with the conjecture that antitakeover amendments decrease shareholder wealth"); Gregg A. Jarrell \& Annette B. Poulsen, Shark Repellents and Stock Prices: The Effects of Antitakeover Amendments Since 1980, 19 J. FIN. ECON. 127, 136 (1987) ("Antitakeover amendments reduce firm value by reducing the probability of receiving valuable takeover bids."); Lucian A. Bebchuk \& Alma Cohen, The Cost of Entrenched Boards (Nov. 2003) (unpublished manuscript, on file with author), available at http://www.law.harvard.edu/programs/olin_center/corporate_governance /papers/03.bebchuk-cohen.entrenched-boards.pdf; Robert Daines, Do Classified Boards Affect Firm Value? Staggered Boards After the Poison Pill 27 (unpublished manuscript, on file with author) (finding that "classified boards reduced shareholder wealth by roughly $2 \%$ "). But see Victoria B. McWilliams, Managerial Share Ownership and the Stock Price Effects of Antitakeover Amendment Proposals, 45 J. Fin. 1627, 1639 (1990) (arguing that on average, antitakeover amendments do not produce a significant stock price reaction). For an analysis of the weaknesses of all but the Daines and BebchukCohen methodologies, see generally John C. Coates IV, Takeover Defenses in the Shadow of the Pill: A Critique of the Scientific Evidence on Takeover Defenses, 79 TEX. L. REv. 271 (2000).

${ }^{24}$ Lucian Arye Bebchuk, John C. Coates IV \& Guhan Subramanian, The Powerful Antitakeover Force of Staggered Boards: Theory, Evidence, and Policy, 54 STAN. L. REV. 887 (2002).

${ }^{25}$ Kenneth A. Borokhovich et al., CEO Contracting and Antitakeover Amendments, 52 J. FIn. 1495, 1504 tbl.I (1997).

${ }^{26}$ Gerald T. Garvey \& Gordon Hanka, Capital Structure and Corporate Control: The Effect of Antitakeover Statutes on Firm Leverage, 54 J. FIN. 519 (1999). 


\section{INSTITUTIONAL SHAREHOLDERS AND TAKEOVER DEFENSES AT THE IPO STAGE}

While institutional investors were engaged in proxy battles against management of public companies to declassify their boards and to place poison pills under shareholder control: classified boards were becoming increasingly common in the charters of IPOs, and shareholder control over poison pills was wholly absent. In this context, however, there has been no battle. Indeed, until recently, institutional shareholders were entirely silent. Between 1987 and 1999, approximately 6000 firms went public, ${ }^{27}$ and roughly half had staggered boards. ${ }^{28}$ Moreover, over the course of that period, the percentage of companies with staggered boards increased.

In most cases, institutions do not directly own shares of companies at the time they go public. Consequently, they have no opportunity to directly influence the terms of the charters those companies adopt. By virtue of their investments in private equity funds, however, institutions do indirectly own shares of companies going public. Between 1987 and 1999, private equity firms funded over thirty percent of the companies that went public. ${ }^{29}$ By the time these companies go public, private equity funds typically own a majority of their shares. ${ }^{30}$ Fund manágers sit on their boards and wield substantial influence over company management. Most of the money in private equity funds comes from institutional investors, including public pension plans. Consequently, one would expect private equity-backed firms to have charters that reflect institutional investors' views regarding takeover defenses.

Reality, however, has not been in line with this expectation. As displayed in Table 4, classified boards have become common among those companies that private equity firms take public, and the use of classified boards has more than doubled among companies going public between 1988 and 1998. Furthermore, restrictions on

${ }^{27}$ SDCA-Thompson Financial Securities Data (TFSD), Worldwide Mergers \& Acquisitions, available at DIALOG, File No. 551.

${ }^{28}$ I estimate this proportion by multiplying the number of IPOs that went public each year by the applicable percentages in Table 4 below. For 1987, I used the percentage for the period from 1988 to 1992 . For 1993, I used the percentage for the period from 1994 to 1997.

${ }^{29}$ SDCA, supra note 27. Among firms listed in this database, after excluding real estate investment trusts, closed-end mutual funds, and other corporations with 4-digit SIC codes beginning with "67" (Holding and other Investment Offices), thirty percent are listed as having venture capital investment.

${ }^{30}$ Daines \& Klausner, supra note 1 , at 93 , tbl.1. 
management's ability to adopt poison pills are absent, as are other governance provisions that institutions support in the proxy context.

Table 4: Antitakeover Defenses in IPO Charters ${ }^{31}$

\begin{tabular}{|c|c|c|c|c|c|}
\hline \multicolumn{7}{|c|}{ Classified Boards } \\
\hline & Total & $\mathrm{N}$ & VC & LBO & $\begin{array}{c}\text { Non- } \\
\text { VC/LBO }\end{array}$ \\
\hline $1988-1992$ & $36.2 \%$ & 1019 & $37.0 \%$ & - & $35.5 \%$ \\
\hline $1994-1997$ & $43.5 \%$ & 310 & $43.4 \%$ & $47.2 \%$ & $40.7 \%$ \\
\hline 1998 & $66.0 \%$ & 162 & - & - & - \\
\hline 1999 & $82.0 \%$ & 33 & - & - & - \\
\hline
\end{tabular}

\begin{tabular}{|c|c|c|c|c|c|}
\hline \multicolumn{6}{|c|}{ Shareholders Cannot Call Special Meeting or Vote By Written Consent } \\
\hline & Total & $\mathrm{N}$ & $\mathrm{VC}$ & LBO & $\begin{array}{c}\text { Non- } \\
\text { VC/LBO }\end{array}$ \\
\hline & & & & & \\
\hline $1988-1992$ & $12.4 \%$ & 1019 & $14.0 \%$ & - & $10.9 \%$ \\
\hline $1994-1997$ & $24.5 \%$ & 310 & $23.6 \%$ & $33.2 \%$ & $15.9 \%$ \\
\hline 1998 & $51.2 \%$ & 162 & - & - & - \\
\hline 1999 & $84.8 \%$ & 33 & - & - & - \\
\hline
\end{tabular}

The contrast between institutions' highly visible advocacy of takeover-friendly charters in the proxy context and their silence at the IPO stage was puzzling. The explanation, however, appears simple: institutional investors were apparently unaware of the fact that companies were going public with takeover defenses in their charters. On September 25, 2000, Shannon P. O'Brien, treasurer of the Commonwealth of Massachusetts, delivered a speech to the Council of Institutional Investors (Council) on "expanding the Council's corporate governance policies into the private equity arena." In that speech, O'Brien brought the issue to the attention of Council members and

${ }^{31}$ Laura Casares Field provided the data for 1988-92 from the data used in Field \& Karpoff, supra note 1, at 1858 (2002). The source of data for the years from 1994 to 1997 is Daines \& Klausner, supra note 1, at 96 . John Coates provided data for the years 1998-99 from data used in Coates, supra note 1, at 1376-77. Blank cells indicate unavailable data.

${ }^{32}$ Massachusetts Treasurer Shannon O'Brien, Remark to the Council of Institutional Investors 1 (Sept. 25, 2000) (on file with author) [hereinafter O'Brien, Remarks]. 
encouraged them to raise it with the managers of the private equity funds in which they invest: ${ }^{33}$

A recent study by McKinsey \& Company attempts to prove what all of us already knew. According to McKinsey, institutional investors around the world will pay a "good governance" premium of up to $20 \%$ to buy the stock of companies that are structured to serve the interests of shareholders, rather than management. ${ }^{34}$

But another recently published study contains a much more troubling finding, and has received far less attention (perhaps because it was published in something called the Journal of Law, Economics, and Organization $)^{95}$ This article, by Michael Klausner of Stanford and Robert Daines of NYU, concludes that many new, "IPO stage" companies have corporate charters with provisions-such as antitakeover provisionsthat are harmful to shareholder interests. Many of these "IPO stage" companies are financed by venture capital and LBO funds, which in turn are supported by many of the institutional investors in this room.

Now, we know that institutional investors like good corporate governance, and that good governance leads to more profitable investments. And we certainly know that the general partners of venture capital and LBO funds like profitable investments. So it seems to me that if we-as institutional investors - try to educate general partners about the benefits of good governance for their portfolio company investments, we ought to have a receptive audience. (And since most of the general partners' funds come from us, we might even have a captive audience.)

This ought to be an easy sell: to my fellow pension trustees, to our general partners, and-ultimately-to our portfolio companies.

${ }^{33}$ Of course, individual institutions may have been aware of the takeover defenses in IPO charters. The fact that Treasurer O'Brien delivered this speech to Council members suggests, at least, that such awareness was not widespread and certainly had not risen to such a level that institutions were taking any action.

${ }^{34}$ The McKinsey study referred to is Paul Coombes \& Mark Watson, Three Surveys on Corporate Governance, MCKINSEY Q. No. 4, at 74-77 (2000). The authors of the study conducted a survey in which they asked institutional investors what percentage premium they would pay for shares of a company with governance qualities such as an independent board and stock-based compensation for directors. Id. The mean answer for respondents in the United States was eighteen percent. Id. at 76 exhibit 2. More sophisticated efforts to measure the relationship between governance structures and share value in the U.S. have not come close to this number.

${ }^{35}$ Daines and I had somehow missed the McKinsey study, probably because it was published in something called the McKinsey Quarterly. (Daines and I were also unaware of Treasurer O'Brien's speech or the actions of the Council, until I began researching this Article).

${ }^{36}$ O'Brien, Remarks, supra note 32 , at 2-3. 
Treasurer O'Brien's speech led to the Council's adoption of the following language in the preamble of its Corporate Governance Policies:

[C]onsistent with their fiduciary obligations to their limited partners, the general partners of venture capital, buyout and other private equity funds should use appropriate efforts to encourage the companies in which they invest to adopt long-term corporate governance provisions that are consistent with the Council's policies. ${ }^{37}$

In addition, the Council adopted a model letter, available on its Web site, for members to send to the private equity funds in which they invest. ${ }^{38}$ The letter recites the research that Treasurer O'Brien cited and goes on as follows:

We recognize that the general partners of venture capital and buyout funds have strong economic incentives to maximize the value of IPO stage companies in which they have invested. ...

Once an initial public offering has been completed, however, the general partners of venture capital and buyout funds have relatively shortterm investment horizons-at least when compared to their institutional limited partners....

... [I]nstitutional investors expend significant time and resources encouraging good governance of publicly traded companies, where their leverage as shareholders is relatively weak and the obstacles to reform are formidable. Many of these institutional investors also happen to be important-if not predominant-sources of capital for venture capital and buyout funds, which can have enormous leverage over privately-held IPO stage companies. ${ }^{39}$

The letter then goes on to quote the language that the Council had added to its Corporate Governance Policies and states, "we hope to encourage our general partners to pay more attention to the post-IPO governance structures of their portfolio companies."

Finally, the Council drafted and made available to its members model contract language to be included in private equity partnership agreements. That language provided as follows:

The General Partner shall use reasonable efforts, consistent with its fiduciary obligations to the Partnership and its primary obligation to

37 Policies, supra note 14; see also Council of Institutional Investors, Council Research Service. Alerts, Mar. 29, 2001 (on file with author) (announcing that Council members voted to adopt this language).

${ }^{38}$ Council of Institutional Investors, Model Letter, at http://www.cii.org (n.d.) [hereinafter Model Letter].

${ }^{39}$ Id.

${ }^{40} I d$. 
maximize the value of the Fund's holdings for the benefit of its Limited Partners, to encourage the Partnership's portfolio companies to adopt corporate charters and long-term corporate governance structures that are consistent with the Council of Institutional Investors' Core Policies, General Principles, and Positions . . ; provided, however, that (i) a portfolio company shall be considered to have acted in full compliance with this provision if it adopts such corporate charter provisions with an effective date deferred up to three years following the date it first becomes a publicly-traded company, and (ii) a portfolio company's failure to adopt such corporate charter provisions and governance structures shall not be considered a breach of the Partnership Agreement or give rise to any liability on the part of the General Partner.

Although the Council's policy statement, model letter, and model contract provision indicate that institutional investors are making efforts to prevent companies from going public with charter provisions that institutional investors oppose, there is a stark contrast between the language used in these documents and institutional investors' posture in the proxy context. In its Corporate Governance Policies, the Council states that private equity fund managers "should use appropriate efforts to encourage [portfolio companies] to adopt long-term corporate governance provisions that are consistent with the Council's Policies." ${ }^{42}$ That same language is quoted in the model letter, and similar language is included in the model contract provision. What does the Council mean by "long-term corporate governance provisions"? Classified boards, and other takeover defenses included in the charter, are the primary provisions that come to mind. Presumably, the Council means that portfolio companies should not have classified boards, and they should not prohibit shareholders from voting by written consent or calling a special meeting. The Council, presumably, also means that portfolio companies should have charter provisions that require shareholder ratification of a poison pill. But why beat around the bush? Why did they not say this explicitly? Also, what efforts to promote the adoption of Council-approved provisions would be "appropriate" under the terms of the policy statement and the model letter? What efforts would be inappropriate? Under the model partnership agreement provision, what are "reasonable" efforts? Would it be "appropriate" or "reasonable" for a private equity fund to vote its shares only in favor of a takeover-friendly charter-that is, one that complies with the Council's policies-and to decline to vote its

${ }^{41}$ Council of Institutional Investors, Proposed Partnership Agreement Provision, at http://www.cii.org (n.d.) [hereinafter Agreement].

${ }^{42}$ Policies, supra note 14. 
shares in favor of a takeover-unfriendly charter? Such actions are obviously within the province of a shareholder and certainly appear "appropriate" and "reasonable" for a shareholder who opposes takeover defenses, as the Council does. Since funds typically own a majority of their portfolio companies' shares, voting those shares would be all that is necessary to produce a charter that is consistent with the Council's Policies. Why didn't the Council specify its desires more explicitly?

The model letter and the model contract language further weaken the Council's position. The letter says only that the institution investing in the fund "hope[s] to encourage" the fund to "pay more attention" to governance structures. ${ }^{43}$ The contract language turns out not to be contract language after all-it undoes itself by providing that a breach of the provision will not be a breach of contract. ${ }^{44}$ It thus has no more effect than a statement of desire, along the lines of the policy statement and the model letter. These weak and equivocal expressions of the Council's position, regarding private equity IPO governance, stand in stark contrast to the Council's position in the proxy context, which is absolute and forceful in its insistence on takeover-friendly charters and other governance structures that it advocates.

The Council's efforts to have private equity funds join institutional investors' effort to rid charters of takeover defenses raise two related questions. First, why has the Council been so much less forceful in this context than in the proxy context? Second, what are institutional investors' prospects for success in persuading private equity funds to impose takeover-friendly charters on their portfolio companies? The underlying question is whether the dynamics of governance decisions made by private equity funds and portfolio company managers at the IPO stage contain hidden barriers to institutional investors' goals. The answer, as discussed below, may well be "yes."

\section{A NeW COlLECTIVE ACTION PROBLEM FOR INSTITUTIONAL INVESTORS}

One could reasonably expect that ridding IPO charters of takeover defenses would be easy. Until recently, academics were unanimous in their certainty that the incentives of pre-IPO shareholders and managers would generally lead to the adoption of takeover-

Model Letter, supra note 38

${ }^{44}$ Agreement, supra note 41. 
friendly charters at the time of an IPO. ${ }^{45}$ The now-familiar logic was that pre-IPO shareholders both control the corporation and stand to reap the benefits of a higher share value, both in the IPO and in the secondary market. Pre-IPO shareholders' incentive, therefore, is to maximize share value. Empirical studies have shown that takeover defenses reduce share value. ${ }^{46}$ Consequently, pre-IPO shareholders would be expected to adopt takeover-friendly charters. The exception would be firms in which managers stood to reap high private benefits of control by adopting takeover defenses. In that case, management would "buy" takeover defenses from other pre-IPO shareholders via some sort of transfer payment-perhaps, a reduction in management's share ownership or post-IPO compensation. ${ }^{47}$

The logic, underlying the expectation of takeover-friendly charters at the IPO stage, is strongest for companies with private equity funds as shareholders. Managers of these funds are sophisticated businesspeople who, one would expect, seek to maximize the value of their investments in portfolio companies. They are experienced in corporate governance, they are well positioned to understand the effect of takeover defenses on the value of a firm, and they generally hire sophisticated lawyers to shepherd portfolio companies through the IPO process. Moreover, they play an active, if not dominating, role in managing the companies in their portfolios. It would appear unlikely, therefore, that takeover defenses would find their way into the charters of firms in a fund's portfolio.

The widespread presence of takeover defenses in the charters of firms with private equity fund investment (and in the charters of other firms as well) suggests that there is a flaw in this logic. The relatively weak language of the Council of Institutional Investors' policy statement, model letter, and model contract provision, quoted above, suggests that institutional investors recognize that convincing private equity funds to impose takeover-friendly charters on their portfolio companies may not be the "easy sell" that Treasurer O'Brien predicted in her speech. ${ }^{48}$ Robert Daines and I have offered some tentative hypotheses regarding the general presence of takeover defenses

${ }^{45}$ Supra notes 1-2 and accompanying text.

${ }^{46}$ See sources cited supra note 22.

${ }^{47}$ For the classic statements of this proposition, see EASTERBROOK \& FISCHEL, supra note 1, at 196-98; Michael C. Jensen \& William H. Meckling, Theory of the Firm: Managerial Behavior, Agency Costs and Ounership Structure, 3 J. FIN. ECON. 305, 313, 32428, 351-52 (1976).

${ }^{48}$ O'Brien, Remarks, supra note 32 , at 3. 
in IPO charters. ${ }^{49}$ In this Volume, Lucian Bebchuk and Lynn Stout further explore those hypotheses and also offer some others. ${ }^{50}$ In this Part, I develop an alternative hypothesis that applies only to IPO firms with private equity investment.

Private equity funds compete in two markets simultaneously. They compete for institutional investors' funds, and they compete for businesses in which to invest those funds. One would expect, focusing solely on the competition for institutional investors' funds, that institutions would have an easy time convincing private equity funds to impose takeover-friendly charters on their portfolio companies. The adoption of takeover-friendly charters would be necessary to meet the demands of the market, and if the institutions are correct about the impact of takeover defenses on share value, the adoption of takeoverfriendly charters would enhance the value of the fund managers' investments to boot.

If one focuses instead on the second market-private equity funds' competition to attract companies in which to invest-the analysis becomes more complicated. Both the receptiveness of private equity funds to the institutions' argument for takeover-friendly charters, and the likelihood that institutions will press the argument become unclear. Venture capital funds need to attract entrepreneurs in search of funding. In some cases, leveraged buyout firms work the same way, attracting managers seeking to go private or to sell a division. $^{5 l}$ For each type of fund, access to investment opportunities may turn, at least in part, on maintaining a positive reputation for working well with the managers of their portfolio companies, especially successful managers. Consequently, an important concern for a fund considering an institutional investor's demand for takeover-friendly charters is whether the fund's reputation for working well with management is at risk if the fund imposes such a charter on portfolio

49 See Daines \& Klausner, supra note 1, at 111-13 (offering four possible explanations for the pattern of the continued adoption of antitakeover protections).

${ }^{50}$ See generally Lucian Arye Bebchuk, Why Firms Adopt Antitakeover Arrangements, 152 U. PA. L. REV. 713 (2003); Lynn A. Stout, The Shareholder as Ulysses: Evidence on Why Investors in Public Corporations Tolerate Board Governance, 152 U. PA. L. REV. 667 (2003) [hereinafter Stout, Shareholder as Ulysses].

${ }^{51}$ There are surely complexities in the reputations different funds choose to develop and preserve. $\mathrm{LBO}$ funds that specialize in hostile takeovers or that routinely replace incumbent managers are presumably unconcerned with their reputation among managers of firms they acquire. Similarly, some venture capitalists may choose to reduce managers' expectations of retaining their jobs through a public offering. My only point is that, for some private equity firms, this reputation will be important. 
companies that go public. To be sure, private equity fund managers are known to be tough with portfolio company managers. They fire many before a company goes public. Portfolio company managers in place at the time of an IPO, however, tend to be successful managers. A fund may be reasonably concerned, therefore, that if it opposes the wishes of these managers at this stage, the fund will develop a reputation for mistreating demonstrably successful managers, as opposed to managers that it feels do not measure up. If reputational damage is possible, the fund could reasonably resist an institution's demand. ${ }^{52}$ Indeed, the fund manager would explain to the institution that, as an investor in its fund, the institution itself should not want the fund to risk attractive "deal flow" in exchange for takeover-friendly charters. Moreover, the explanation would be delivered to the institution's investment staff, who are likely to be a more receptive audience than the corporate governance specialists who run the institution's proxy voting process.

The question, therefore, is whether a fund's insistence on takeover-friendly charters may feed a reputation that the fund is uncooperative with even its most successful managers. This is ultimately an empirical question, but there is reason to expect the answer will be "yes."

My hypothesis is as follows: The interest of a private equity fund in creating and maintaining a reputation for treating successful management well has led, and will continue to lead, funds to allow portfolio companies to adopt takeover defenses in their charters at the time of an IPO.

To begin the development of the hypothesis, I adopt the conventional assumptions that takeover defenses in company charters are detrimental, and that the IPO market and secondary markets set share

${ }^{52}$ See Bernard S. Black \& Ronald J. Gilson, Venture Capital and the Structure of Capital Markets: Banks Versus Stock Markets, 47 J. FIN. ECON. 243, 254-55 (1998), in which the authors posit an implicit contract between the venture capitalist (VC) and the entrepreneur in which the latter transfers control to the former subject to the condition that, if the start-up is successful, the VC transfers control back to the entrepreneur by allowing the start-up to go public. This implicit contract is enforced by a reputational sanction for a VC that declines to take a successful company public. While I am not arguing that there is or is not an implicit contract to allow an entrepreneur to adopt takeover defenses, my point parallels that of Black and Gilson. It is based both on private equity funds' need to attract successful start-ups and LBO prospects, and on the possible risk to a fund's reputation and, therefore, its ability to attract future investment opportunities if the fund does not accede to the demands of successful managers. 
prices that reflect the presence of these defenses. ${ }^{53}$ Under these assumptions, management would seek takeover defenses whenever the protection of its private benefits is worth the cost in terms of the negative impact that defenses would have on management's shares. The fewer shares held by management and the greater its private benefits, the more likely it is that the trade off for management will favor defenses. The cost of these takeover defenses would be borne in part by the private equity fund (and any other non-management shareholders that may exist prior to the IPO).

When a portfolio company is about to go public, a private equity fund could respond to management's desire for takeover defenses in any of three ways: it could refuse to approve a takeover-unfriendly charter; it could ask management for some form of compensation in return for approving takeover defenses in the charter; or, it could offer to compensate management for accepting a takeover-friendly charter. $^{54}$ Any of these responses is potentially awkward and could put a fund's reputation for working well with successful management at risk. The first problem is that the starting point of the discussion between management and the fund would be ambiguous. On the one hand, assuming the fund holds a majority of the company's shares, it would have the legal right to determine the content of the company's charter. $^{55}$ On the other hand, especially in light of the large number of

${ }^{53}$ The presence of takeover defenses in a firm's charter is publicly disclosed and the negative impact of defenses on share value has been documented. See supra note 47. For the purpose of this analysis, therefore, the starting point must be that the market discounts the shares of firms that employ takeover defenses. As discussed below, if the market does not discount the shares of firms with defenses, the theoretical support for the hypothesis would be stronger. See infra text accompanying notes 87-93 (discussing the implication of Bebchuk's "bounded attention" hypothesis).

${ }^{54}$ It is theoretically conceivable that the fund has already implicitly agreed to allow portfolio companies to adopt takeover defenses and has included in the valuation of its investment in the company whatever cost that may entail. Such an agreement may be part of the implicit contract that Black and Gilson infer, regarding the commitment of a venture capitalist to return control of the firm to the entrepreneurs by allowing successful companies to go public. Black \& Gilson, supra note 52, at 258-59. I am doubtful that such an implicit deal exists. There is no evidence of such a deal in the practitioner literature on venture capital. Moreover, the fact that takeover defenses are not universal indicates that this is not a case in which all parties involved have such a clear understanding of the deal that there is no need to discuss or comment on it.

${ }^{55}$ It could do so either by exerting its control over the board or by withholding votes in a shareholder vote to approve adoption of the charter. Prior to an IPO, venture capitalists on average own $54 \%$ of the share of firms in which they invest. Daines \& Klausner, supra note 1 , at 93 tbl.1. Leveraged buyout funds on average own $74.8 \%$ of firms in which they invest. Id. Although I refer to the fund in the singular, there is commonly more than one fund invested in a company at the time the company goes 
firms that have gone public in the past decade with takeover defenses in their charters, management could well view the use of defenses as within its prerogative and, therefore, view a fund's exercise of its legal power as a greedy, heavy-handed grab for a few dollars of share value at the expense of management's well-deserved, post-IPO comfort. ${ }^{56}$

To avoid the awkwardness of the starting point, the fund could begin by conceding the starting point to management and offering to compensate management for accepting a takeover-friendly charter. ${ }^{57}$ Compensation could take the form of cash, additional stock, or stock options. Even this dialogue, however, could be difficult. Management would have difficulty translating into dollars (or additional shares) the private benefits associated with takeover defenses, and the fund would have difficulty estimating the impact of takeover defenses on the value of their shares. The value of a takeover-friendly charter would not be uniform across companies. The cost of takeover defenses for a company depends on the likelihood that an acquisition bid will be made, the expected premium, and the probability that management would resist an attractive bid. This, in turn, depends on the industry involved, management's shareholdings, the nature and extent of managers' private benefits, the career options of managers, and other factors. A fund that offers less than what management believes takeover protection is worth could appear cheap at best, and oppressive at worst. Consequently, even if a fund were to give management the initial entitlement to takeover defenses, an attempt to negotiate back to a takeover-friendly charter could still be difficult and potentially risky to the fund's reputation.

public, especially in the case of venture capital backed firms. I assume for simplicity that the funds can coordinate with one another in responding to management's request for takeover defenses.

${ }^{56}$ If this issue arose in the mid-1980s, when classified boards and other charterbased takeover defenses began to have an impact, the result might have been different. Once a large number of companies have takeover defenses at the time of their IPO, expectations are formed, and it is more difficult to turn back the tide without incurring a reputational cost. See generally Marcel Kahan \& Michael Klausner, Path Dependence in Corporate Contracting: Increasing Returns, Herd Behavior, and Cognitive Biases, 74 WASH. U. L.Q. 347 (1996) (explaining how cognitive bias can have the same effect); Marcel Kahan \& Michael Klausner, Standardization and Innovation in Corporate Contracting (Or "The Economics of Boilerplate"), 83 VA. L. REV. 713 (1997) (describing network externalities that encourage standardization in corporate contracts); Michael Klausner, Corporations, Corporate Law, and Networks of Contracts, 81 VA. L. REV. 757 (1995) (explaining the lock-in caused by network externalities in contracts).

${ }^{57}$ Unless management's private benefits exceed the reduction in aggregate, nonmanagement share value attributable to the defenses, this is a trade that could place both parties in a better position. 
The difficulty the fund faces in this context goes beyond the ambiguity of starting positions and valuation, and potential friction with portfolio company managers. The risk to the fund's reputation stems as well from the way the fund's behavior will be portrayed to, or perceived by, other entrepreneurs. The word-of-mouth descriptions of a fund's behavior in this context are inevitably imperfect. Even if a fund behaves reasonably in negotiating takeover defenses, the fund's reputation may suffer.

Rather than engage in difficult negotiations with the management of a successful portfolio company on the eve of its IPO and subject its future to the perils of an imperfect reputation market, a fund could reasonably choose to avoid the issue entirely. It may thus allow a company to adopt a takeover-unfriendly charter if management so desires, or if a lawyer happens to include takeover defenses in the company's charter. ${ }^{58}$ Empirical studies measuring the impact of classified boards on share value estimate a range of values from one to five percent. ${ }^{59}$ This would be the range of values a fund would gain by forcing a non-classified board upon management without compensation or, alternatively, by insisting that management compensate it for adopting a classified board. The net savings would be less, of course, if a fund were to compensate management for accepting such a charter. ${ }^{60}$ Private equity funds could well conclude that the risk to their reputation of even raising the issue is not worth the potential gain.

The difficulty that a private equity fund could experience in negotiating a takeover-friendly charter suggests the following hypothesis: Transaction costs in negotiating takeover defenses with a company's management and information imperfections regarding the impact of those negotiations on a private equity fund's reputation may explain the frequency with which takeover defenses appear in the charters of companies in which funds invest. The benefit of a higher share value may be overwhelmed by the cost that a fund would bear in losing other attractive investment opportunities. If this hypothesis is correct,

See Coates, supra note 1 , at 1303 (showing that the presence of takeover defenses depends in large part on the company's lawyer).

${ }^{59}$ See sources cited supra note 22.

${ }^{60}$ One could reasonably be skeptical of this story in light of the fact that private equity fund managers are known to be tough business people and that they frequently fire CEOs of portfolio companies. Venture capitalists routinely have conversations with managers prior to the time they invest in a company, in which they warn that the $\mathrm{CEO}$ and other top managers may be replaced. A conversation about employing takeover-friendly charters, if and when the company goes public, would be no more awkward than this conversation. On the other hand, the stakes may be lower. 
one would expect fund managers to resist institutions' efforts to promote takeover-friendly charters among companies going public. Moreover, one would expect institutions to tread lightly in pushing funds to insist on takeover-friendly charters because they will bear the cost if funds are hampered in their ability to build a valuable portfolio.

Lucian Bebchuk argues in response to this Article that takeover defenses must be efficient for my hypothesis to be valid. ${ }^{61} \mathrm{He}$ describes a scenario in which a fund, at the time it makes its investment in a portfolio company, implicitly agrees to include a takeover defense in its charter if the company goes public. The fund will do so, Bebchuk argues, only if it expects the defense to maximize the value of the firm. This is not my hypothesis. Although, as Bebchuk states, this argument is consistent with "standard and familiar reasoning," ${ }^{62}$ I am doubtful that this explains the presence of takeover defenses in these firms. My hypothesis relies instead on transaction costs of negotiation and imperfections in the development of a fund's reputation.

If this hypothesis is correct, private equity funds will force managers to accept takeover-friendly charters only if institutional investors collectively insist that doing so will be a condition of obtaining their investment dollars. If this occurs, private equity funds would have no choice but to accommodate the institutions' demands. Moreover, so long as all funds are affected, none would suffer a competitive disadvantage in doing so. Portfolio company managers would also know that the source of the disturbance is not the intransigence of fund managers, but rather the demands of the ultimate investors. At this point, however, with institutions exerting relatively little pressure individually and no significant coordinated pressure, the need to attract companies in which to invest seems likely to dominate the views of private equity funds toward takeover defenses.

\section{OTHER EXPLANATIONS FOR TAKEOVER DEFENSES AT THE IPO STAGE}

Elsewhere in this Volume, Lucian Bebchuk and Lynn Stout also attempt to explain the presence of takeover defenses in the charters of firms going public. They do so without differentiating between companies with private equity funding and those that are funded by managers themselves or by other sources. ${ }^{63}$ Most of Bebchuk's

\footnotetext{
61 Bebchuk, supra note 50 , at $746-48$.

${ }^{62}$ Id. at 747.

${ }^{63}$ Id. at 746-48; Lynn A. Stout, Shareholder as Ulysses, supra note 50, at 701; see gener-
} 
explanations, however, are inapplicable to firms with private equity fund investment, and those explanations that apply are, at least, questionable. Stout's explanation, if valid, would apply to all firms, regardless of whether they have private equity investment, but I am doubtful of her explanation. I address their explanations below.

\section{A. Takeover Defenses as a Mechanism to Promote Deconcentration Ownership in the Future}

Two of Bebchuk's explanations turn on the possibility that a firm will have investment opportunities in the future requiring a new issuance of equity that would dissipate management's control block. In the first explanation, Bebchuk suggests that takeover defenses provide managers with sufficient protection from an unwanted acquisition to encourage them to "deconcentrate ownership" by issuing new shares when a profitable investment opportunity arises in the future. ${ }^{64}$ Without this protection of their private benefits of control, Bebchuk posits, management may forgo profitable investment opportunities in favor of retaining control. ${ }^{65}$ According to this explanation, the market understands the relationship between defenses and future expansion and, for firms with concentrated ownership at the time of the IPO, places a higher value on firms with defenses than on those without defenses. ${ }^{66}$ Consequently, pre-IPO shareholders benefit from takeoverunfriendly charters. ${ }^{67}$

In his second explanation, Bebchuk posits that managers may actually be willing to deconcentrate ownership without takeover defenses when a profitable investment opportunity appears, but only if rewarded for a takeover-friendly charter with an appropriately high share price in the IPO and thereafter. ${ }^{68}$ Bebchuk then posits, however, that asymmetry of information may exist regarding whether a particular company is likely to have such profitable investment

ally Lynn A. Stout, Do Antitakeover Defenses Decrease Shareholder Wealth? The Ex Post/Ex Ante Valuation Problem, 55 STAN. L. REV. 845 (2002) [hereinafter Stout, Valuation Problem].

${ }^{64}$ See Bebchuk, supra note 50, at 730-33 (discussing the inducement to deconcentrate ownership as the first of several efficiency-based explanations for IPO and midstream behavior).

${ }^{65}$ Id. at 731-32.

id. at 731 .

${ }^{67}$ In this scenario, the theoretical, first-best alternative of no takeover defense coupled with management willingness to dissipate ownership is not available. The takeover defense is, thus, the best of the second-best alternatives that are available.

${ }^{68}$ Bebchuk, supra note 50, at 731 . 
opportunities in the future. ${ }^{69}$ If the market cannot distinguish between companies that will have opportunities and those that will not, or those that are more likely to have opportunities from those that are less likely, it will not adequately value the absence of takeover defenses. ${ }^{70}$ Consequently, those managers whose predictions of future investment opportunities are more optimistic than the prediction of the market will decline to adopt takeover-friendly charters, and a pooling equilibrium will occur in which all firms adopt takeoverunfriendly charters. ${ }^{71}$

Neither of these explanations applies to firms with private equity financing because, in these firms, management does not hold a control block following the IPO. In effect, ownership of these firms is fairly well dispersed at the time of the IPO. ${ }^{72}$ In my study with Daines, we found that for firms with venture capital investment, the top five managers held an average of $18.9 \%$ of a company's outstanding shares following an IPO. ${ }^{73}$ For firms with leveraged buyout fund investment, this figure was $8.9 \% .{ }^{74}$ At least for the venture capital-backed companies, share ownership will likely disperse further as management sells some shares. Consequently, for firms that had private equity investment prior to their IPO, the presence of takeover defenses cannot be explained by a future need to deconcentrate share ownership. ${ }^{75}$ Indeed, if Bebchuk's first explanation were correct-that takeover defenses encourage de-concentration of ownership-one would expect fewer defenses in firms with private equity investment than in

\footnotetext{
${ }^{69} I d$. at 739 .

${ }^{70}$ Id. at 740

${ }^{71} \mathrm{Id}$.
}

${ }^{72}$ The private equity fund holds a control block temporarily, but that block will typically be distributed to the fund's investors shortly after the IPO. In some cases, LBO funds retain their shares, but either way, management will not have control, and there is no reason to believe that LBO funds will resist an expansion opportunity.

${ }^{73}$ Daines \& Klausner, supra note 1, at 93 tbl.1.

${ }^{74}$ Id. Total director and officer shareholdings reported in a prospectus are larger $-45.4 \%$ and $39.6 \%$, respectively-for firms with venture capital and LBO fund investment. $I d$. These figures are larger because they include shares held by directors associated with the venture capital or LBO fund. These shares will become dispersed within a few years following the IPO, and in the meantime, these directors will not protect management's private benefits.

${ }^{75}$ Even for companies without private equity investment, it seems unlikely that the existence of asymmetric information will be common regarding investment opportunities in the distant future. If such asymmetric information exists, one would expect to find it in firms that rely heavily on research and development. Daines and I found, however, that these firms were less likely than others to adopt takeover defenses. Daines \& Klausner, supra note 1, at 101 tbl.3. 
firms without such investment. That expectation, however, is contradicted by the data. ${ }^{76}$

\section{B. Efficient Preservation of Private Benefits}

Bebchuk next suggests that takeover defenses may be present where they efficiently preserve management's private benefits of control-that is, where management's private benefits are greater than their cost in terms of lost aggregate share value. ${ }^{77}$ In this scenario, as Bebchuk describes it, management bears the full cost of takeover defenses, apparently as a result of owning all pre-IPO shares and accepting a lower share price once the company goes public. ${ }^{78}$ In some firms, he argues, takeover defenses have a greater positive effect on private benefits than their negative effect on share value for pre-IPO shareholders. ${ }^{79}$ In those firms, management makes a rational choice of takeover protection, and since no one else is affected, the choice maximizes firm value. This scenario also fails to fit the private equity context. For companies with private equity investment, private equity funds hold most of the pre-IPO shares. For firms with venture capital, this ownership level is $54 \%$, and for those with LBO fund investment, the figure is $74.8 \%{ }^{80}$ Thus, the fund would bear most of the cost of a takeover defense, while management reaps the benefit.

In theory, Bebchuk's efficiency explanation for takeover defenses could apply to a firm with private equity investment. The story, however, would be more complicated and less plausible. There are three possible scenarios: (a) management would have to compensate the fund for the use of takeover defenses (by giving up shares, for example); (b) the fund would have to bear the cost because it lacks the bargaining power to insist on a takeover-friendly charter; or, (c) the fund would simply have to make a gift to management of the takeover defense. There is no basis for inferring that any of these scenarios accurately reflects what is going on when a private equity-backed firm adopts takeover defenses. If any of these explanations were accurate, one would expect to see at least some evidence in press reports of disputes between private equity funds and company managers regarding the adoption of defenses or, perhaps, discussions in the business

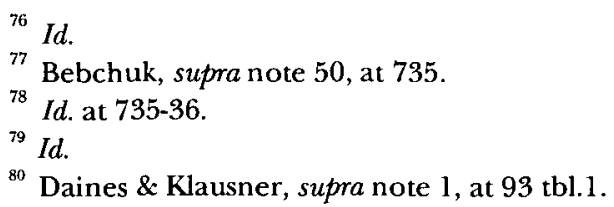


or legal practitioner press of how funds and management might bargain over defenses. Yet, to my knowledge, no such evidence exists. Also, if the adoption of takeover defenses is explained by weak bargaining power on the part of funds, one would expect to see evidence of such weakness with respect to other extractions of wealth by portfolio company management at the time of the IPO. I am unaware of any such evidence.

Moreover, it is unclear what sort of private benefit Bebchuk has in mind when he says that the protection of private benefits may be efficient. Protection of high compensation (or other rents) cannot be efficient, since whatever management gains comes dollar-for-dollar at the expense of shareholders. ${ }^{81}$ Private benefits could arise as a result of having the company enter into transactions with another company owned by management. So, as long as the terms of the transactions are at arm's length, protection of such benefits could possibly be efficient. But it seems unlikely that this situation will commonly exist, especially among firms with private equity investment. Perhaps Bebchuk has in mind psychic benefits of control. These benefits may well exist, and perhaps there are gains from protecting them with takeover defenses, but are those gains large enough to offset the costs of defenses to shareholders? Perhaps, but the results of the study that Daines and I conducted cast doubt on this explanation. We analyzed whether firms in which founders were still CEOs at the time of the IPO were more likely to have takeover defenses than were firms whose founders had been replaced as CEO. ${ }^{82}$ Our assumption was that founder-CEOs would derive relatively high psychic benefits from retaining control of the firm and would, therefore, derive greater private benefits overall than would other managers. We found, however, that there was no statistically significant difference in takeover defenses between firms with and without founder-CEOs. ${ }^{83}$

\section{Pre-IPO Agency Costs}

Bebchuk next offers two explanations based on pre-IPO agency costs, neither of which can account for takeover-unfriendly charters in

${ }^{81}$ Field \& Karpoff, supra note 1, at 1869-70, find that management compensation is higher in firms with takeover defenses than in firms without defenses. They do not

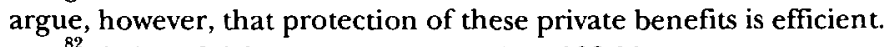

${ }_{82}^{82}$ Daines \& Klausner, supra note 1, at 108-10.

${ }^{83} I d$. at 108 (describing the results of a regression analysis used to test the private benefit hypothesis). 
the private equity context. ${ }^{84}$ In one scenario, managers dominate "passive and uninformed" nonmanagement shareholders. ${ }^{85}$ This clearly does not describe private equity funds. In the other scenario, lawyers are the culprits, and the pre-IPO shareholders are unable to monitor what lawyers write into a company's charter. ${ }^{86}$ Once again, the scenario does not fit-private equity funds are fully able to instruct and monitor the lawyers working on an IPO of a portfolio company. They are repeat players in the IPO game, they know the issues and choices that arise, and they have ongoing relationships with the law firms that represent their portfolio companies as they go public. There is no reason to believe that law firms make decisions that cut against the interests of private equity fund investors.

\section{Pricing of Takeover-Unfriendly Charters}

Finally, Bebchuk offers a "bounded attention" rationale, a fancy way of saying that the securities markets do not price takeover defenses, and a heresy in law and economics circles. ${ }^{87}$ Daines and I suggested this as well, and we, too, left it for last (having failed to come up with a more respectable explanation) ${ }^{88}$ If takeover-unfriendly charters are not priced, then pre-IPO shareholders would have less reason to oppose management's desire to protect itself. ${ }^{89}$

Although this may well be the reason why takeover defenses are so common at the IPO stage, the explanation is not without problems, as Daines and I discussed in our article. First, since pre-IPO shareholders typically hold their shares until after the IPO, the pricing failure must be present both in the IPO market and in the secondary market following the IPO. But why would such a pricing failure occur and

${ }^{84}$ See Bebchuk, supra note 50, at 736-39 (describing agency costs arising from divergent incentives of lawyers, managers, and shareholders).

${ }^{85}$ Id. at $735-36$.

${ }^{86}$ Id. at $736-39$.

${ }^{87}$ Id. at $740-45$.

${ }^{88}$ One senior colleague of ours, upon hearing of our suggestion, commented, "So, I hear you believe that, after 600 years of securities market experience, the market does not know how to price takeover defenses." Another senior colleague warned my then-untenured coauthor that including this sort of explanation in our article could jeopardize his tenure. On the other hand, I have yet to meet a single capital market professional-investment banker, venture capitalist, lawyer, or stock analyst-who believes that takeover defenses are priced when included in a charter at the time a company goes public.

${ }^{89}$ A shareholder expecting to hold shares for the long term, during which time a hostile bid could occur, would still oppose defenses. 
persist over many years? Empirical research has shown that takeover defenses are detrimental to shareholders, ${ }^{90}$ and the presence of a takeover defense in a firm's charter is visible to the market. So why should it not be priced, either in the IPO or in the secondary market after the IPO? Second, when takeover defenses are imposed midstream, by charter amendment or state legislation, event studies show an impact on share prices. ${ }^{91}$ Why would defenses be priced at the midstream stage but not at the IPO?

Bebchuk attributes the difference to the fact that a defense "will impact shareholders only when (and if) the company will move to dispersed ownership down the road. ${ }^{, 92}$ His argument is based on the fact that shareholdings tend already to be dispersed at the midstream stage and concentrated at the time of the IPO and thereafter for several years. Therefore, Bebchuk argues, the probability of a takeover defense ever becoming relevant is lower when it is adopted at the IPO stage than when it is adopted at the midstream stage. As stated above, however, for firms with private equity investment, shareholdings are in effect dispersed as of the time of the IPO. Consequently, this explanation does not apply to these firms. ${ }^{93}$

Lynn Stout has made a related point regarding the present value of the future impact of a takeover defense. Stout argues that, due to the time value of money, the future impact of a defense should be discounted to present value as of the time of the IPO. ${ }^{94}$ Her discounting point is incorrect-for companies with or without private equity investment. While it is true that one would discount the expected value of a takeover defense, one must also inflate the expected value by a factor that reflects the expected growth of the firm-and hence the expected growth of the takeover premium and the expected growth in

${ }^{90}$ See supra notes 23-26 and accompanying text (stating that the adoption of defenses is commonly followed by increases in management compensation, increase in free cash flow, and decreases in shareholder wealth).

${ }^{91}$ See supra note 23.

${ }^{92}$ Bebchuk, supra note 50 , at 741 . Bebchuk also argues that shareholders pay more attention because they view them in isolation from other aspects of the company. It is unclear why this should matter if share prices actually reflect all publicly available information about a company.

${ }^{93}$ For firms without private equity investment, Bebchuk's point applies only if a firm is expected to exist for a finite period of time (and if the end of its existence, by merger for instance, is not related to the presence of a takeover defense). While this assumption of a less than infinite life is reasonable in a technical sense, the longer a firm is expected to exist, the weaker Bebchuk's point becomes.

${ }^{94}$ Lynn A. Stout, Valuation Problem, supra note 63, at 859. Stout argues that this is why takeover defenses in charters do not have sunset provisions. 
the benefit of reduced agency cost. Inflating by growth and discounting for time should at least be a wash. ${ }^{95}$

A final problem with the notion that defenses are not priced is that the absence of defenses in so many charters would be difficult to explain. Why are defenses not present in all charters? One answer to that question, suggested by Table 4 , is that we may be reaching that point. But what took so long?

If takeover defenses are not priced (or if they are underpriced), my hypothesis regarding defenses in firms with private equity investment would be even stronger, and it will be even more unlikely that institutional investors will succeed in having private equity funds impose takeover-friendly charters on their portfolio companies. Private equity funds and their investors could sell their shares following the IPO and, therefore, avoid any cost that a takeover defense may impose on shareholders (by actually reducing the likelihood of a future acquisition or by reducing a company's share value if the market eventually does price the defense). ${ }^{96}$ The fund could maintain a reputation for treating successful managers well with no cost to itself or its investors.

\section{E. The Team Production Explanation}

Lynn Stout argues, consistent with a "team production" hypothesis that she and Margaret Blair have developed elsewhere, ${ }^{97}$ that firms protect themselves from takeovers in order to ensure that they make good on implicit promises made to management and employees. ${ }^{98}$ The hypothesis is that firms make implicit promises of greater compensation or other future benefits in exchange for management and

${ }^{95}$ To the extent that a defense will, with some probability, deprive shareholders of a future takeover premium, an element of a defense's cost is the value of the lost premium. The value of the lost premium as of the time of the IPO is its expected value, discounted for the time value of money and inflated for the expected growth in the company and therefore growth in the absolute value of the premium. A second element of the cost of a takeover defense is the attenuation of the disciplinary impact that the market for corporate control can have on management. To the extent that this reduction in agency costs occurs in the future, it should be discounted for the time but also inflated for the company's expected growth, since management can expect to have more to lose as the company grows. Discounting for the time value of money and inflating for expected growth should at least cancel each other out.

${ }_{96}$ An index fund, on the other hand, might not be able to sell the shares.

${ }^{97}$ Margaret M. Blair \& Lynn A. Stout, A Team Production Theory of Corporate Law, 85 VA. L. REV. 247 (1999).

${ }_{98}$ See Stout, Valuation Problem, supra note 63, at 852 (arguing that assurances of stability, such as antitakeover defenses, are necessary to gain the trust of employees at the beginning of a new venture). 
employees investing in firm-specific human capital and working harder than their explicit current compensation would warrant. If a third party were to acquire the company before the firm confers these future benefits on management and employees, the acquirer could expropriate some of this yet-to-be-delivered wealth for itself. By paying a premium for the firm's shares, the acquirer would share that wealth with current shareholders. Accordingly, Stout posits that takeover defenses are used to protect the expectation of management and employees and thereby help encourage management and employees to increase their current effort, which creates a current benefit for shareholders. ${ }^{.9}$ Consequently, Stout argues, while takeover defenses have a negative impact on shareholders ex post, once a bidder is willing to pay a premium for a company's shares, they may have a positive impact ex ante, when management and employees are working harder and investing in firm-specific skills. ${ }^{100}$

I am doubtful that Stout's story fits the facts, at least in the case of firms with private equity investment. Beginning at the time of the private equity fund's investment, high turnover among managers and other employees is common. Venture capitalists routinely fire CEOs, and start-up employees frequently change jobs. ${ }^{101}$ LBO funds often acquire a company precisely in order to reorganize it, which means firing employees from the CEO on down. In addition, these firms are commonly sold rather than taken public, and, upon sale, managers and employees are fired. With turnover so common, it is unlikely that managers or employees rely on implicit promises of future compensation. What they receive instead are explicit promises in the form of stock or stock options. There is no reason to believe that the form of compensation changes-that implicit promises suddenly come into play-when a company goes public, particularly because we continue to see stock-based explicit compensation in place.

Stock and stock options not only promise rewards if a company succeeds, they promise rewards if the company is acquired. If the sale of one's vested stock is insufficient to elicit management or employee effort, a firm can adopt additional mechanisms, such as accelerated vesting or payments triggered by a change of control. In contrast to

${ }^{99}$ Stout, Shareholder as Ulysses, supra note 50, at 709-10.
${ }_{100}$ Stout, Valuation Problem, supra note 63, at 848.
${ }_{101}$ See, e.g., Ronald J. Gilson, The Legal Infrastructure of High Technology Industrial Districts: Silicon Valley, Route 128, and Covenants Not To Compete, 74 N.Y.U. L. REV. 575, $590-92$ (1999) (describing a high turnover rate of employees in Silicon Valley and Route 128 technology companies). 
takeover defenses, these mechanisms allow employees to be rewarded if a takeover occurs without allowing management to obstruct a takeover bid. Moreover, these mechanisms protect employees from friendly takeovers as well as hostile ones. In Stout's analysis, the only protection employees enjoy from friendly takeovers is the trustworthiness of management. ${ }^{102}$ For Stout's thesis to be valid, one would have to believe that these common forms of compensation are inadequate to generate maximum employee and management effort, that takeover defenses are a necessary supplement to protect expectations, and that the marginal ex ante gain is worth the cost to shareholders of allowing management to block an attractive acquisition offer. I am doubtful that this set of conditions often exists.

\section{CONCLUSION}

Institutional investors have been slow to respond to the widespread presence of takeover defenses in the charters of firms whose shares they hold through private equity funds, and their response to date has been tepid compared to their efforts in the proxy context. Institutional investors' hesitancy may reflect a rational unwillingness among private equity funds-as well as the institutions' own investment staff, as opposed to their governance-oriented proxy voting departments-to require portfolio companies to go public with takeoverfriendly charters.

This Article has developed a hypothesis to explain both the common presence of defenses in the charters of firms that go public with private equity investment and the half-hearted response of institutional investors to this situation. Under this hypothesis-based on private equity funds' need to maintain a reputation for dealing well with successful managers of portfolio companies-it is privately rational, but socially inefficient, for private equity funds to have their portfolio companies adopt takeover defenses. The implication of the hypothesis is that institutional investors may face at least as difficult a challenge in ridding IPO charters of takeover defenses as they face in urging managers of already-public firms to eliminate defenses from their charters.

102 See Stout, Valuation Problem, supra note 63, at 855 (describing antitakeover defenses and dual class stock as part of a larger pattern of shareholder preference for ceding control to a board). 